\title{
Kandungan beta karoten, polifenol total dan aktifitas "merantas" radikal bebas kefir susu kacang hijau (Vigna radiata) oleh pengaruh jumlah starter (Lactobacillus bulgaricus dan Candida kefir) dan konsentrasi glukosa
}

\author{
Teguh Supriyono ${ }^{1,2}$, Retno Murwani ${ }^{2,3}$, Nurrahman $^{4}$
}

\begin{abstract}
Background: Kefir is a well known fermented dairy milk product which is functional for gut health. However kefir can also be made from vegetable milk such as soy or mungbean milk.

Objective: To study the chemical and functional property of Mungbean milk (MBM) Kefir

Methods:Mungbean milk was fermented into MBM Kefir using Lactobacillus bulgaricus and Candida kefir. Three levels of cultures and glucose concentration were tested and a complete randomized design experiment was employed. The resulting MBM Kefir were tested for $\beta$-carotene level, total polyphenol content, and free radical scavenging activity. Beta carotene level, total polyphenols and free radicals scavenging activity were determined by spectrophotometry, Folin-Ciocalteu method, and DPPH radical scavenging assay respectively. The data were analyzed by ANOVA and when the result of ANOVA was significant, Tukey's multiple comparison was conducted.

Results: Culture concentration increased $\beta$-carotene level $(p=0.049)$, total polyphenol $(p=0.015)$ and free radical scavenging activity $(p=0,000)$ of MBM kefir. Glucose concentration increased total polyphenol $(p=0.002)$, but had no effect on free radical scavenging activity and $\beta$-carotene level. However, there were no interaction among treatments at 0.05 significance level. Total acid level ranged from 1.57 to $2.54 \%$, with the highest and level at $15 \%$ cultures concentration and $15 \%$ glucose concentration. Alcohol level ranged from 0.26 to $0.90 \%$ which was in accordance with the maximum standard for kefir $(1 \%)$.

Conclusion: An optimal product of mungbean milk kefir with highest free radical scavenging activity can be obtained using $15 \%$ cultures (Lactobacillus bulgaricus and Candida kefir) and $10 \%$ glucose concentration.
\end{abstract}

Keywords: Lactobacillus bulgaricus, Candida kefir, $\beta$-carotene, totalpolyphenol, free radicals scavenging activity.

\begin{abstract}
ABSTRAK digunakan. kacang hijau. alkohol berkisar 0,26\% - 0,90\% sesuai dengan literatur yaitu maksimal $1 \%$.

1 Jurusan Gizi Politeknik Kesehatan Kemenkes Palangka Raya, Indonesia

${ }^{2}$ Fakultas Peternakan dan Pertanian, Universitas Diponegoro, Indonesia

${ }^{3}$ Natural Product Laboratory-Centre of Research and Services Universitas Diponegoro Semarang, Indonesia

4 Jurusan Teknologi Pangan, Fakultas Ilmu Keperawatan dan Kesehatan, Universitas Muhammadiyah Semarang, Indonesia
\end{abstract}

Latar belakang : Fermentasi susu kacang hijau dengan penambahan kultur Lactobacillus bulgaricus dan Candida kefir dapat meningkatkan sifat fungsionalnya. Sumber energi utama dari kedua mikroorganisme tersebut adalah laktosa, sementara susu kacang hijau tidak mengandung laktosa. Kandungan gula dalam susu kacang hijau sebagai sumber energi bagi mikroorganisme sangat terbatas, sehingga diperlukan penambahan glukosa sebagai sumber energi yang dapat langsung

Tujuan : Penelitian ini bertujuan untuk menganalisis pengaruh jumlah starter (Lactobacillus bulgaricus dan Candida kefir) dan konsentrasi glukosa terhadap kadar beta karoten, polifenol total dan aktivitas "merantas" radikal bebas kefir susu

Metode : Penelitian ini adalah eksperimen murni. Rancangan percobaan disusun menggunakan Rancangan Acak Lengkap. Kadar beta karoten ditentukan dengan spektrofotometer, polifenol total dianalisis menggunakan reagen Folin-Ciocalteu dan aktivitas "merantas" radikal bebas ditetukan dengan DPPH radical scavenging assay. Data yang diperoleh dianalisis menggunakan uji ANOVA, jika ada pengaruh yang signifikan dilajutkan dengan uji beda Tukey HSD.

Hasil penelitian : Jumlah starter berpengaruh nyata terhadap kadar beta karoten $(p=0,049)$, polifenol total $(p=0,015)$ dan aktivitas "merantas" radikal bebas $(p=0,000)$. Ada pengaruh konsentrasi glukosa terhadap polifenol total ( $p=0,002)$, sedangkan aktivitas "merantas" radikal bebas dan kadar beta karoten tidak dipengaruhi oleh konsentrasi glukosa dan tidak ada interaksi pada semua perlakuan. Tingkat signifikansi yang digunakan adalah 0,05. Kadar total asam berkisar 1,57\% $2,54 \%$, dengan kadar tertinggi pada perlakuan jumlah starter $15 \%$ dan konsentrasi glukosa $15 \%$, sementara untuk kadar

Simpulan : Kefir susu kacang hijau dengan sifat fungsional yang optimal menggunakan jumlah starter (Lactobacillus bulgaricus dan Candida kefir) $15 \%$ dan konsentrasi glukosa 10 $\%$.

Kata kunci : Lactobacillus bulgaricus, Candida kefir, beta karoten, polifenol total, aktivitas "merantas" radikal bebas. 


\section{PENDAHULUAN}

Fermentasi merupakan teknik yang tidak saja murah namun juga alami untuk menghasilkan dan mengawetkan makanan. Dalam proses fermentasi dengan adanya aktifitas enzim dari mikroba, komponen-komponen seperti pati, lemak, protein, zat toksik dan senyawa anti gizi dapat dipecah. Teknik fermentasi ini memunculkan banyak ketertarikan untuk diaplikasikan pada bahan pangan kacang kacangan karena adanya efek peningkatan zat gizi dan pengaruh yang baik bagi kesehatan. ${ }^{1}$

Produk fermentasi susu dapat berupa yoghurt atau kefir, tergantung dari jenis mikroorganisme yang digunakan selama fermentasi. Kefir adalah produk yang dihasilkan dari fermentasi susu sapi yang telah dipasteurisasi kemudian ditambahkan starter berupa butir atau biji kefir (kefir grain/kefirgranule).

Kefir dapat pula dibuat menggunakan bahan baku susu nabati yaitu dari kacang-kacangan. Kelebihan susu nabati sebagai bahan baku susu fermentasi adalah kandungan lemak yang rendah dan tidak mengandung kolesterol. Kacang hijau merupakan bahan pangan lokal yang dapat digunakan sebagai bahan baku susu fermentasi. Kacang hijau mengandung senyawa - senyawa fungsional diantaranya $\beta$-karoten dan polifenol. Senyawa senyawa ini telah diketahui memiliki sifat fungsional sebagai antioksidan dan immunomodulator. Kemampuan $\beta$-karoten sebagai antioksidan ditunjukkan dalam mengikat radikal oksigen $\left({ }^{1} \mathrm{O}_{2}\right)$, "merantas" atau merapuhkan radikal peroksil dan menghambat oksidasi lipid, sedangkan polifenol mampu "merantas" oksigen dan radikal alkil dengan memberikan donor elektron sehingga terbentuk radikal fenoksil yang relatif stabil. ${ }^{2}$

Satu hal yang penting pada fermentasi menggunakan bakteri asam laktat (BAL) dengan bahan baku dari susu kacang-kacangan adalah jenis karbohidratnya yang berbeda dengan karbohidrat pada susu sapi. Susu kacang-kacangan mengandung oligosakarida dan polisakarida sedangkan pada susu sapi adalah laktosa. ${ }^{3}$ Kandungan gula yang terdapat dalam susu kacang hijau yang dapat dimanfaatkan oleh mikroorganisme yang berperan dalam proses pembuatan kefir sangat terbatas, oleh karena itu perlu dilakukan penambahan gula sebagai sumber karbon.

Glukosa adalah gula dalam bentuk sederhana yang dapat langsung dimanfaatkan oleh mikroorganisme untuk pertumbuhannya. Diharapkan dengan penambahan glukosa pertumbuhanLactobacillus bulgaricus dan Candida kefir dapat dipacu. Pembuatan kefir dengan bahan baku susu kacang hijau belum pernah dilakukan sebelumnya, danperubahan $\beta$-karoten dan senyawa polifenol selama fermentasi kefir kacang hijau, serta sifat fungsional kefir kacang hijau sebagai antioksidan juga belum diketahui, sehingga dilakukan kajian terhadap perubahan kandungan $\beta$-karoten, polifenol total dan aktifitas "merantas" radikal bebas kefir susu kacang hijau akibat proses fermentasi.

\section{METODE DAN BAHAN}

Materi yang digunakan adalah kacang hijau, air minum, susu sapi segar, kultur murni dari bakteri Lactobacillus bulgaricus dan khamir Candida kefir.

\section{Produksi susu kacang hijau}

Pembuatan Susu Kacang Hijau dilakukan menurut metode Widowati dan Masgiyarta(2007). ${ }^{4}$ Kacang hijau yang telah dipisahkan dari kotoran dan biji rusak direndam dalam air dengan perbandingan air dengan kacang hijau 3 : 1 selama 8 jam. Kacang hijau ditiriskan dan dididihkan selama 20 menit. Kemudian kacang hijau digiling menggunakan waring blender. Bubur (slurry) kacang hijau yang diperoleh ditambah air mendidih sehingga jumlah air secara keseluruhan mencapai 8 kali lipat bobot kacang hijau kering. Bubur encer disaring dengan kain kasa dan filtratnya merupakan susu kacang hijau. Susu kacang hijau dipasteurisasi pada suhu $85^{\circ} \mathrm{C}$ selama 30 menit.

\section{Pembuatan Starter Kefir}

Medium yang digunakan untuk membuat starter kefir yaitu susu sapi yang dipasteurisasi pada suhu $85^{\circ} \mathrm{C}$ selama 30 menit. Susu didinginkan sampai suhu ruang dan kemudian ditambahkan kultur murni dari bakteri Lactobacillus bulgaricus dan khamir Candida kefir dengan rasio 1 : 1 .Susu diinkubasi pada suhu ruang selama 20 jam dandidinginkan pada suhu $10^{\circ} \mathrm{C}$ selama 2 hari untuk pematangan. Jumlah mikroorganisme pada starter $(\mathrm{CFU} / \mathrm{ml})$ dihitung dengan metode TPC (Total Plate Count) sehingga diketahui jumlah mikroorganisme yang akan ditambahkan. Starter yang digunakan memiliki jumlah mikroorganisme $4,0 \times 10^{6} \mathrm{cfu} / \mathrm{ml}$.

\section{Pembuatan Kefir Susu Kacang Hijau}

Susu kacang hijau dipanaskan pada suhu $85^{\circ} \mathrm{C}$ selama 30 menit, dan ditambahkan glukosa sesuai perlakuan yaitu 5\%, $10 \%$ dan $15 \%$. Susu kacang hijau selanjutnya didinginkan pada suhu ruang.Setelah dingin ditambahkan starter kefir yang mengandung kultur murni Lactobacillus bulgaricus dan Candida kefirsesuai perlakuan yaitu sebanyak 5\%,10\% dan $15 \%$. Susu kacang hijau yang telah ditambahkan dengan starter diinkubasi pada suhu $43,5^{\circ} \mathrm{C}$ selama 6 jam dalam inkubator. Kefir susu kacang hijau yang dihasilkan kemudian didinginkan pada suhu $10^{\circ} \mathrm{C}$ selama 2 hari untuk menghambat pembentukan alkohol oleh khamir. Setelah itu kefir susu kacang hijau langsung dianalisis. 


\section{Rancangan Penelitian}

Rancangan percobaan disusun menggunakan Rancangan Acak Lengkap pola faktorial 2 x 3, dimana masing-masing satuan percobaan diulang sebanyak 3 kali. Faktor I adalah jumlah starter dan Faktor II adalah konsentrasi glukosa, masing-masing faktor terdiri dari 3 (tiga) level. Untuk melihat pengaruh perlakuan yaitu jumlah starter dan konsentrasi glukosa terhadap $\beta$-karoten, polifenol total, dan aktifitas "merantas" radikal bebaskefir susu kacang hijau, datadiujistatistik menggunakan Analysis of Varians (ANOVA) dansoftware SPSS 11.5.Apabila diantara perlakuan terdapat pengaruh nyata maka dilanjutkan dengan uji beda dengan mengunakan uji Tukey Honestly Significance Difference (HSD) pada taraf $5 \% .^{5}$

\section{Pengukuran kadar $\beta$-carotene ${ }^{6}$}

Sampel kefir sebanyak $1 \mathrm{ml}$ ditambah aquades 8 $\mathrm{ml}$ dan dihomogenkan dengan vortex. Dua $\mathrm{ml}$ dari campuran diambil $2 \mathrm{ml}$ dan dimasukkan dalam tabung reaksi, ditambahkan $2 \mathrm{ml}$ alkohol $96 \%$ dan $10 \mathrm{ml}$ petroleum eter (PE). Setelah dikocok selama 2 menit dengan vortex, dipisahkan menggunakan sentrifus. Lapisan PE diambil dan sisanya diekstrak kembali dengan PE $10 \mathrm{ml}$ dan dipisahkan kembali seperti sebelumnya. Kedua lapisan PE disatukan dan diambil $2 \mathrm{ml}$ untuk dibaca pada Spektrofotometer pada panjang gelombang $450 \mathrm{~nm}$. Kadar $\beta$-karoten $(\mu \mathrm{g} / 100$ $\mathrm{ml}$ ) ditentukan dengan rumus (A x F x 100/0.04)x0,5. $\mathrm{A}$ adalah absorbansi dalam pelarut PEdan $\mathrm{F}$ adalah faktor konversi.

\section{Pengukuran kadar polifenol total ${ }^{7}$}

Sampel kefir sebanyak $1 \mathrm{ml}$ ditambah aquades 75 ml. Kemudian ditambahkan reagen Folin-Ciocalteu sebanyak $5 \mathrm{ml}$. Selanjutkan ditambahkan sodium karbonat jenuh sebanyak $10 \mathrm{ml}$ dan $100 \mathrm{ml}$ aquades. Larutan dihomogenkan menggunakan shaker. Sampel selanjutnya dibaca pada Spektrofotometer pada panjang gelombang $760 \mathrm{~nm}$. Sebagai standar digunakan asam tanat dengan konsentrasi 0-9 mg/ml.

\section{Pengukuran Aktifitas merantas radikal bebas ${ }^{8}$}

Sampel kefir sebanyak $200 \mathrm{ml}$ ditambah dengan $1 \mathrm{ml}$ etanol dan $800 \mathrm{ml}$ buffer Tris- $\mathrm{HCl} 100 \mathrm{mM}$

$\mathrm{pH}$ 7. Kemudian ditambahkan $1 \mathrm{ml}$ DPPH 500mM. Larutan campuran dikocok sampai homogen dan didiamkan selama 20 menit dalam ruang gelap. Selanjutnya larutan dibaca absorbansinya pada spektrofotometer pada panjang gelombang $517 \mathrm{~nm}$. Sebagai standar antioksidan digunakan asam askorbat dengan konsentrasi 0,16-1,28 $\mathrm{mg} / \mathrm{ml}$. Aktifitas merantas sampel (\%) dihitung dengan rumus (1- A sampel $517 \mathrm{~nm} / \mathrm{A}$ blanko $517 \mathrm{~nm}$ ) X 100

\section{Pengukuran Total Asam dan Kadar Alkohol ${ }^{\mathbf{9}}$}

Seluruh sampel diukur total asamnya (asam laktat $)^{10}$ dan kadar alkohol dengan metode distilasi. ${ }^{9}$

\section{HASIL}

\section{Kadar $\beta$-Caroten}

Kadar beta karoten kefir susu kacang hijau oleh pengaruh jumlah starter (L. bulgaricus dan C. kefir) dan konsentrasi glukosa disajikan pada Gambar2. Kadar beta karoten kefir susu kacang hijau berkisar antara 18,24-46,75 $\mu \mathrm{g} / 100 \mathrm{ml}$. Secara umum terjadi peningkatan kadar beta karoten setelah fermentasi dibandingkan sebelum susu kacang hijau difermentasi $(17 \mu \mathrm{g} / 100 \mathrm{ml})$ dan lebih tinggi dibandingkan dengan kefir susu sapi $(12,75 \mu \mathrm{g} / 100 \mathrm{ml})$.

Jumlah beta karoten yang ada menurun karena telah digunakan dalam reaksi penetralan radikal bebas tersebut. Hal ini juga berhubungan dengan total fenol yang menurun pada jumlah starter yang semakin banyak (Tabel 2.).Analisis statistik menunjukkan bahwa jumlah starter berpengaruh terhadap kadar beta karoten $(\mathrm{p}=0.049)$ dan jumlah glukosa tidak berpengaruh. Kadar beta karoten meningkat pada jumlah starter $10 \%$ dan menurun pada jumlah starter $15 \%$. Kadar beta karoten yang tertinggi didapat pada perlakuan dengan jumlah starter $10 \%$ dan konsentrasi glukosa $10 \%$ dibandingkan dengan perlakuan lain.

\section{Polifenol Total}

Polifenol total kefir susu kacang hijau oleh pengaruh jumlah starter ( $L$. bulgaricus dan $C$. kefir) dan konsentrasi glukosa disajikan pada Gambar 2. Polifenol total kefir susu kacang hijau berkisar 0,0384 $\mathrm{mg} / \mathrm{ml}-0,054 \mathrm{mg} / \mathrm{ml}$. Terjadi peningkatan polifenol total selama fermentasi dibandingkan dengan susu kacang hijau sebelum fermentasi $(0,035 \mathrm{mg} / \mathrm{ml})$ dan lebih tinggi dibandingkan dengan kefir susu sapi $(0,017 \mathrm{mg} / \mathrm{ml})$. Analisis statistik menunjukkan bahwa jumlah starter dan jumlah glukosa berpengaruh terhadap kadar total polifenol $(\mathrm{p}=0,015)$.

\section{Aktifitas "Merantas" Radikal Bebas}

Aktifitas "merantas" radikal bebas (free radical scavenging activity) adalah kemampuan antioksidan sebagai "scavenger" radikal bebas seperti peroksida, hidroperoksida atau peroksil lipid sehingga menghambat mekanisme oksidasi (Prakash, 2001).Aktifitas "merantas" radikal bebas kefir susu kacang hijau oleh pengaruh jumlah starter ( $L$. bulgaricus dan $C$. kefir) dan konsentrasi glukosa disajikan pada Gambar 3. Analisis statistik menunjukkan bahwa jumlah starter berpengaruh terhadap kadar total polifenol $(\mathrm{p}=0,015)$ dan jumlah glukosa tidak berpengaruh. 
Tabel 1. Total Asam Kefir Susu Kacang Hijau

\begin{tabular}{cccc}
\hline \multirow{2}{*}{ Jumlah Stater $(\%)$} & $5 \%$ & Konsentrasi Glukosa & $15 \%$ \\
\hline $5 \%$ & $1,57 \pm 0,11590$ & $1,76 \pm 0,47260$ & $2,07 \pm 0,22743$ \\
$10 \%$ & $1,64 \pm 0,03055$ & $1,80 \pm 0,19468$ & $2,15 \pm 0,07095$ \\
$15 \%$ & $1,96 \pm 0,15100$ & $2,06 \pm 0,07638$ & $2,54 \pm 0,29094$ \\
Rata-rata & $1,72 \pm 0,20280$ & $1,87 \pm 0,17770$ & $2,25 \pm 0,23286$ \\
\hline
\end{tabular}

Tabel 2. pH Kefir Susu Kacang Hijau

\begin{tabular}{cccc}
\hline \multirow{2}{*}{ Jumlah Stater (\%) } & $5 \%$ & Konsentrasi Glukosa & $15 \%$ \\
\hline $5 \%$ & $4,35 \pm 0,08000$ & $4,22 \pm 0,10693$ & $3,90 \pm 0,18502$ \\
$10 \%$ & $4,27 \pm 0,10017$ & $4,16 \pm 0,19296$ & $3,82 \pm 0,19672$ \\
$15 \%$ & $4,01 \pm 0,10970$ & $3,96 \pm 0,06658$ & $3,74 \pm 0,05508$ \\
Rata-rata & $4,21 \pm 0,17741$ & $4,11 \pm 0,16417$ & $3,82 \pm 0,15425$ \\
\hline
\end{tabular}

\section{Total Asam}

Tabel 1 dan 2 menunjukkan total asam kefir kacang hijau akibat perlakuan jumlah starter (Lactobacillus bulgaricus dan Candida kefir) dan konsentrasi glukosa. Pada kefir kacang hijau, selain Lactobacillus bulgaricus yang membentuk asam asam organik, Candida kefir juga mempunyai kontribusi dalam pembentukan asam organik seperti asam asetat dan asam laktat, sehingga $\mathrm{pH}$ kefir susu kacang hijau menjadi rendah. Sebagian besar, total asam kefir susu kacang hijau memenuhi Standar Nasional Indonesia (SNI) yang dalam hal ini mengacu pada SNI yoghurt karena SNI untuk kefir belum ada.Analisis statistik menunjukkan bahwa jumlah starter dan jumlah glukosa tidak berpengaruh terhadap total asam dan $\mathrm{pH}$.

\section{Kadar Alkohol}

Pengaruh jumlah starter (Lactobacillus bulgaricus dan Candida kefir) dan konsentrasi glukosa terhadap kadar alkohol kefir kacang hijau disajikan pada Tabel 3. Analisis statistik menunjukkan bahwa jumlah starter dan jumlah glukosa tidak berpengaruh terhadap kadar alkohol.

\section{PEMBAHASAN}

Peningkatan kadar beta karoten setelah fermentasi kemungkinan berasal dari beta karoten yang diproduksi oleh Candida kefir.Candida kefir merupakan khamir seperti fungi (yeast like fungi) yang bersifat chromogenicdan menghasilkan berbagai pigmen antara lain pigmen hijau, kuning, oranye, dan hitam. ${ }^{13,18}$ Diantara khamir yang digunakan dalam fermentasi makanan adalah khamir dari famili Ascomycetous, khamir dari genus Candida dan genus Saccharomyces cerevisiae.Kecenderungan penurunan kadar beta karoten dengan semakin banyaknya jumlah starter karena fermentasi melibatkan beragam tipe reaksi kimia termasuk proses oksidasi. ${ }^{11}$ Semakin banyak jumlah startersemakin meningkatkan reaksi oksidasi sehingga semakin banyak pula hasil samping oksidasi berupa radikal bebas seperti singlet oksigen. Beta karoten yang ada kemudianberperan sebagai antioksidan untuk meredam hasil samping reaksi oksidasi tersebut dan bereaksi dengan radikal bebas menjadi senyawa yang lebih stabil. Selain itu bakteri asam laktat juga menghasilkan hidrogen peroksida $\left(\mathrm{H}_{2} \mathrm{O}_{2}\right)$ yang berperan sebagai prekusor pembentukan radikal bebas selama fermentasi.

Peningkatan kadar polifenol susu kacang hijau selama fermentasi oleh mikroba kefir menandakan bahwa mikroba kefir mampu memproduksi polifenol sebagai metabolit sekunder.

Total polifenol meningkat pada jumlah starter $10 \%$ dan sedikit menurun pada jumlah starter $15 \%$. Penurunan polifenol total kemungkinan disebabkan kondisi asam yang semakin meningkat dengan semakin banyaknya penambahan jumlah starter dan konsentrasi glukosa. Asam yang terbentuk dihasilkan oleh Lactobacillus bulgaricus yaitu dengan mengkonversi glukosa menjadi asam laktat. Selain itu Candida kefir juga dapat mengkonversi glukosa menjadi asam laktat dan asetat.

Reaksi oksidasi dari proses fermentasi ini juga menghasilkan hasil samping berupa radikal bebas seperti yang telah dikemukakan sebelumnya. Polifenol juga akan beraksi sebagai antioksidan seperti halnya beta karoten untuk menetralkan hasil samping reaksi oksidasi tersebut. Namun disini penurunan ini kecil sekali dibandingkan penurunan yang terjadi pada kadar beta karoten (Gambar 1). Hasil ini menandakan bahwa beta karoten digunakan lebih banyak atau lebih tersedia sebagai antioksidan sistim pangan kefir.

Untuk pengaruh kadar glukosa terhadap kadar polifenol hanya terjadi pada jumlah starter 5\%. Pada 
jumlah starter 5\% ini, kadar polifenol total meningkat dari jumlah glukosa 5\% ke 10\% namun kemudian menurun kembali. Perubahan kadar total polifenol ini berhubungan dengan jumlah substrat yang semakin tersedia dengan jumlah glukosa yang meningkat. Penurunan kembali pada jumlah glukosa $15 \%$ karena jumlah starter yang hanya $5 \%$ tidak dapat meningkatkan penggunaan substrat glukosa yang ada sehingga jumlah polifenol sebagai metabolit sekunder juga menurun kembali.

Pada yoghurt, kemampuan "merantas" terhadap radikal bebas dari Lactobacillus bulgaricus lebih besar dibanding dengan Streptococcus thermoplillus. ${ }^{12}$
Gambar 3 menunjukkan aktifitas merantas radikal bebas kefir susu kacang hijau oleh pengaruh jumlah starter (Lactobacillus bulgaricus dan Candida kefir) dan konsentrasi glukosa. Semakin banyak jumlah starter menyebabkan kemampuan "merantas" radikal bebas juga semakin besar Aktifitas"merantas" radikal bebas tertinggi didapat pada perlakuan dengan jumlah starter $15 \%$. Hal ini karena sel dari kultur bakteri asam laktat sendiri memiliki kemampuan "merantas" radikal bebas. Sebagian besar komponen antioksidan pada kefir terakumulasi pada biji kefir (kefir grain). ${ }^{14}$

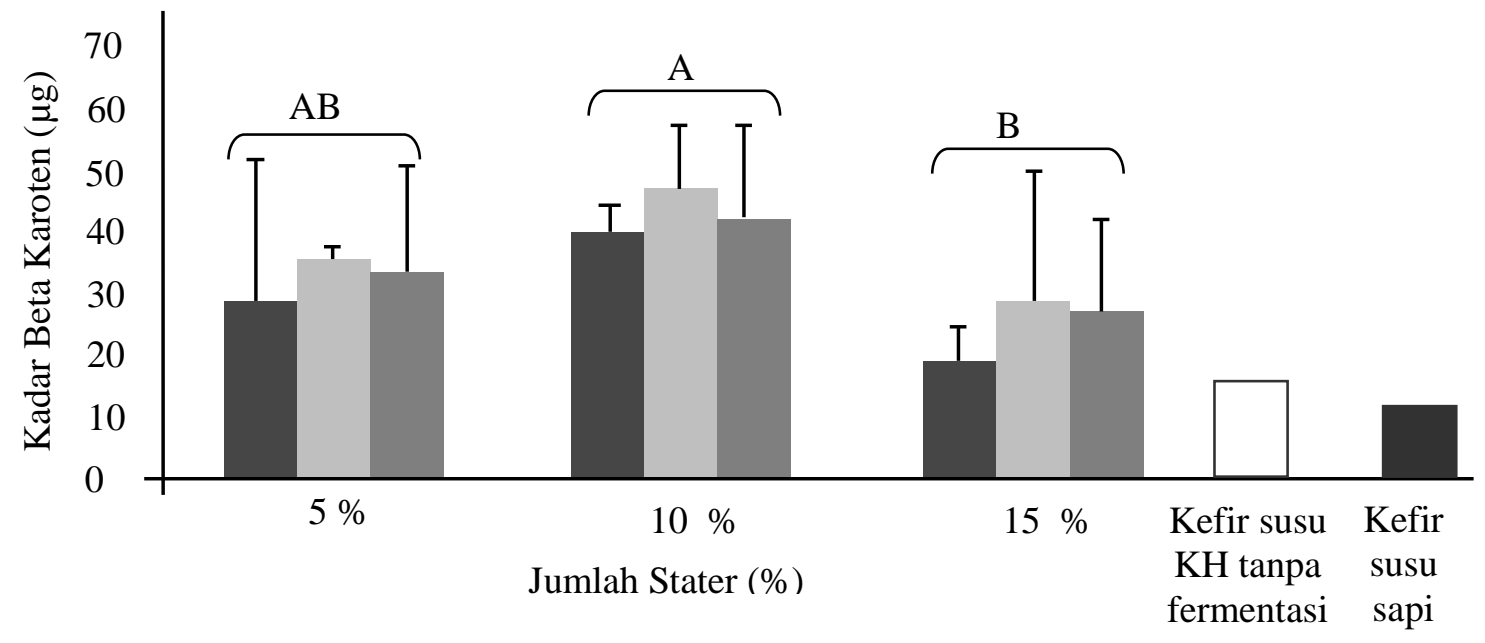

Gambar 1. Kadar B-caroten Kefir Susu Kacang Hijau oleh Pengaruh Jumlah Starter (Lactobacillus bulgaricus dan Candida kefir)dan Konsentrasi Glukosa, dibandingkan dengan kefir susu kacang hijau tanpa fermentasi dan kefir susu sapi. Matriks huruf besar yang berbeda menunjukkan perbedaan nyata jumlah starter.

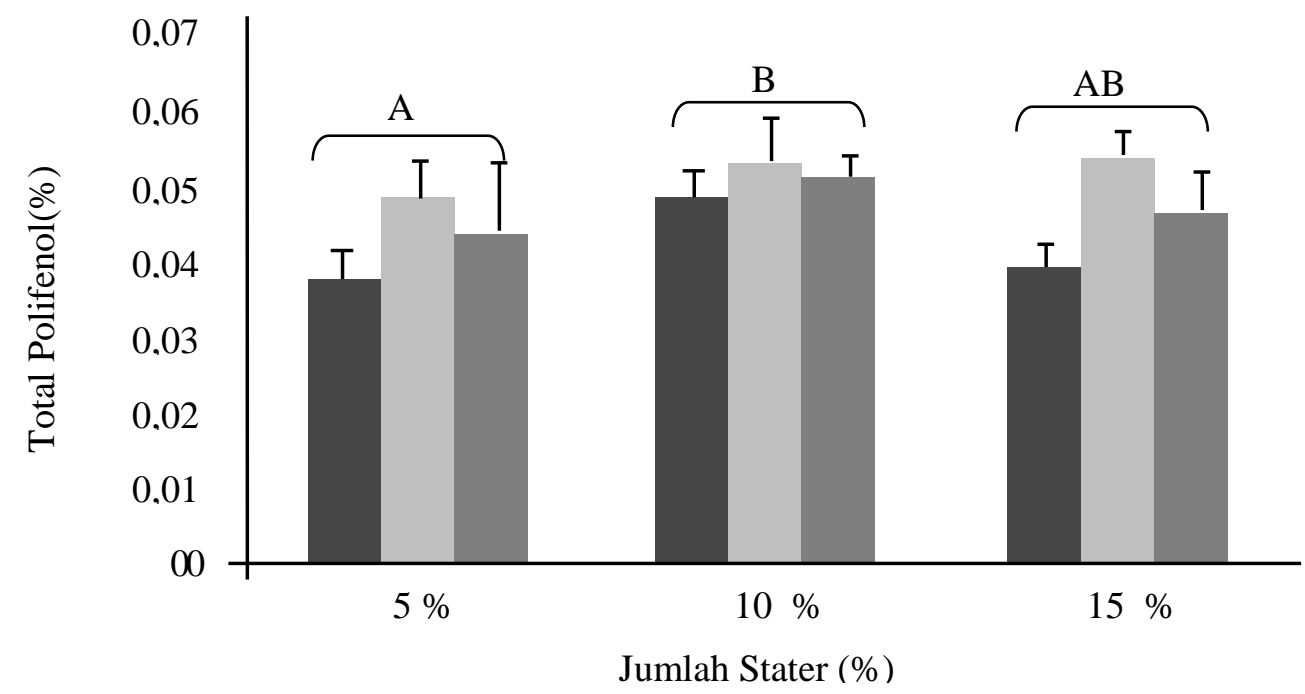

Gambar 2. Total Polifenol Kefir Susu Kacang Hijauoleh Pengaruh JumlahKonsentrasi Glukosa. Matriks huruf besar yang berbeda, menunjukkan perbedaan nyata jumlah starter. Matriks huruf kecil yang berbeda, menunjukkan perbedaan nyata kadar glukosa. Ket : $=$ Glukosa $5 \%, \square=$ Glukosa $10 \%, \square=$ Glukosa $15 \%$ 
Pada yoghurt, Lactobacillus bulgaricus memiliki efek sebagai antioksidan, "merantas" hidroksil radikal, hidrogen peroksida dan malonaldehida pada reaksi oksidasi. Jumlah sel Lactobacillus bulgaricus sebanyak $10^{8} \mathrm{cfu} / \mathrm{mlmenghasilkan} \mathrm{kemampuan} \mathrm{yang}$ tinggi dalam menghambat oksidasi asam lemak. ${ }^{12}$ Sedangkan Candida kefir adalah khamir probiotik yang berperan menyediakan nutrisi seperti asam amino dan vitamin serta mengkondisikan $\mathrm{pH}$ untuk pertumbuhan mikroorganisme lain, ${ }^{13}$ karena khamir mempunyai kemampuan lebih besar dalam mencerna substrat dibanding dengan bakteri asam laktat. ${ }^{14}$

Hanya saja pada perlakuan konsentrasi glukosa $15 \%$, total asam kefir susu kacang hijau diatas ratarata SNI. Hal ini disebabkan konsentrasi glukosa yang lebih tinggi akan menyebabkan produksi asam-asam organik semakin meningkat. Semakin banyak sumber gula yang dapat dimetabolisme maka semakin banyak pula asam-asam organik yang dihasilkan sehingga $\mathrm{pH}$ juga akan semakin rendah. ${ }^{15}$

Sebagian besar khamir memerlukan oksigen untuk pertumbuhannya dan dengan mengontrol oksigen pertumbuhan khamir dapat dikendalikan ${ }^{13}$. Alkohol yang terbentuk selama fermentasi susu kacang hijau menjadi kefir dihasilkan oleh Candida kefir.Candida kefir adalah golongan khamir yang mampu memfermentasi laktosa menjadi glukosa dan galaktosa karena dapat mensintesa enzim laktase dan menghasilkan alkohol dan $\mathrm{CO}_{2}{ }^{16}$ Pada pembuatan kefir susu kacang hijau, fermentasi dilakukan dalam keadaan tertutup. Hal ini dilakukan agar aktifitas khamir dapat dikendalikan sehingga dengan pembatasan oksigen dapat menghambat Candida kefir mengkonversi glukosa yang ditambahkan menjadi alkohol. Selain itu, setelah diinkubasi selama 6 jam pada suhu $43,5^{\circ} \mathrm{C}$, kefir susu kacang hijau langsung dimasukkan kedalam pendingin pada suhu $10^{\circ} \mathrm{C}$. Perlakuan ini juga dimaksudkan untuk menghambat aktifitasCandida kefir sehingga alkohol yang dihasilkan selama fermentasi dapat dikendalikan, ${ }^{19}$ kefir harus disimpan pada suhu rendah agar khamir tidak menghasilkan alkohol dan $\mathrm{CO}_{2}$ yang berlebihan. Kadar alkohol kefir susu kacang hijau memiliki kisaran 0,26-0,90 \%. Kadar alkohol pada susu fermentasi dalam Standar Nasional Indonesia (SNI) belum ada, menghasilkan kadar alkohol kefir sebanyak $0,5-1,0 \% .^{11}$

Tabel 3. Kadar Alkohol (\%) Kefir Susu Kacang Hijau

\begin{tabular}{cccc}
\hline \multirow{2}{*}{ Jumlah Stater $(\%)$} & \multicolumn{3}{c}{ Konsentrasi Glukosa } \\
\cline { 2 - 4 } & $5 \%$ & $10 \%$ & $15 \%$ \\
\hline $5 \%$ & $0,26 \pm 0,03055$ & $0,36 \pm 0,02517$ & $0,49 \pm 0,03055$ \\
$10 \%$ & $0,53 \pm 0,02517$ & $0,63 \pm 0,03000$ & $0,72 \pm 0,03215$ \\
$15 \%$ & $0,62 \pm 0,02517$ & $0,81 \pm 0,01528$ & $0,90 \pm 0,02646$ \\
Rata-rata & $0,47 \pm 0,16508$ & $0,60 \pm 0,20012$ & $0,70 \pm 0,18121$ \\
\hline
\end{tabular}

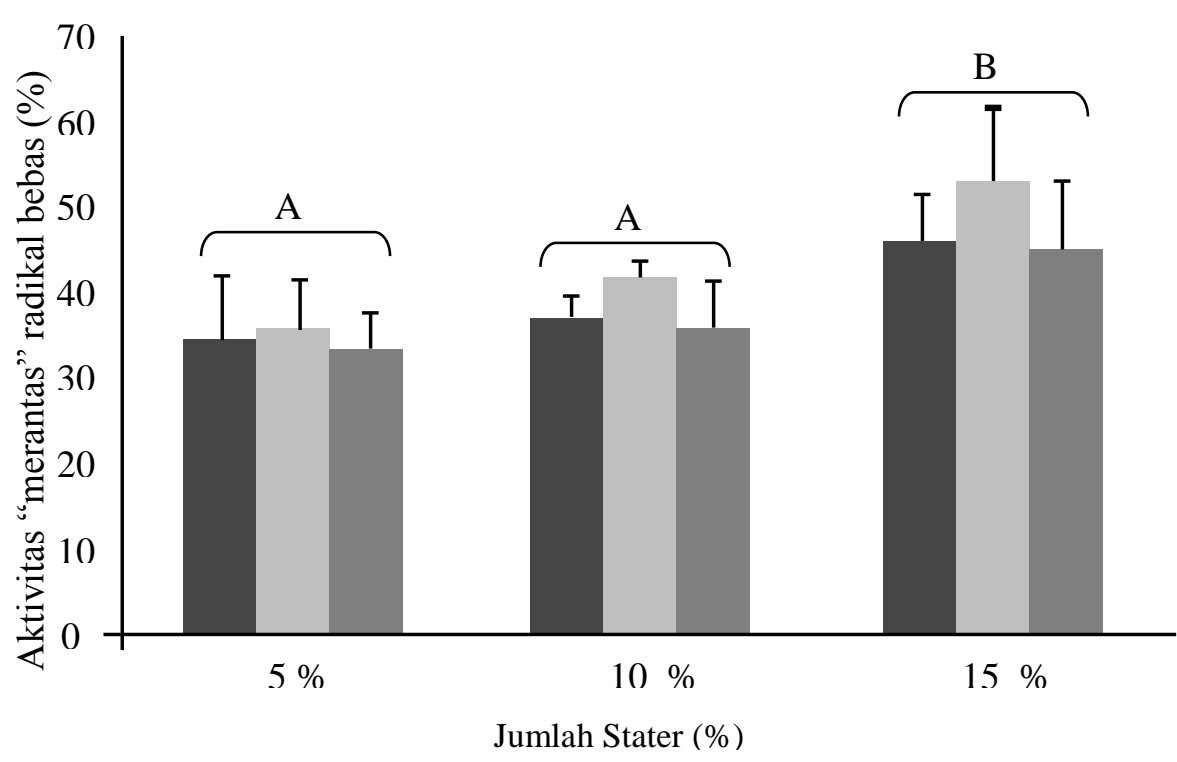

Gambar 3. Aktifitas "Merantas" Radikal Bebas Kefir Susu Kacang Hijauoleh Pengaruh Jumlah Starter (Lactobacillus bulgaricus dan Candida kefir) dan Konsentrasi Glukosa. Matriks huruf besar yang berbeda, menunjukkan perbedaan nyata jumlah starter. Ket: $\square=$ Glukosa $5 \%, \square=$ Glukosa $10 \%, \square=$ Glukosa $15 \%$ 


\section{SIMPULAN}

Kefir susu kacang hijau memiliki aktifitas merantas radikal bebas maksimal pada jumlah starter $15 \%$ dan jumlah glukosa 10\% dengan akhir $\mathrm{pH} 3,96$ dan kadar alkohol $0,81 \%$. Meskipun pada kondisi starter dan kadar glukosa tersebut kadar beta karoten rendah namun kadar polifenolnya tetap tinggi dan menggambarkan bahwa beta karoten digunakan lebih banyak oleh mikroba kefir sebagai senyawa penetral radikal bebas yang muncul selama proses oksidasi (fermentasi).

\section{DAFTAR PUSTAKA}

1. Khalil AA. Nutritional Improvement of an Egyptian Breed of Mung Bean by Probiotic Lactobacilli. African Journal of Biotechnology. 2006;5 (2): 206-212.

2. Mokgope LB. Cowpea Seed Coats and Their Extracts : Phenolic Composition and Use as Antioxidants in Sunflower Oil. South Africa: Department of Food Science. University of Pretoria; June 2006.

3. Yusmarini dan Efendi. Evaluasi Mutu Soygurt yang dibuat dengan Penambahan beberapa Jenis Gula. Jurnal Natur Indonesia. 2004; 6(2): 104110.

4. Widowati, S dan Misgiyarta. Efektifitas Bakteri Asam Laktat (BAL) dalam Pembuatan Produk Fermentasi Berbasis Protein/Susu Nabati. Prosiding Seminar Hasil Penelitian Rintisan dan Bioteknologi Tanaman. Balai Penelitian Bioteknologi dan Sumberdaya Genetik Pertanian; 2007.

5. Steel RGD, Torrie JH. Prinsip dan Prosedur Statistika: Suatu Pendekatan Biometrik. Edisi Kedua. Dialihbahasakan oleh Bambang Sumantri. Jakarta: PT. Gramedia Pustaka Utama; 1993.

6. Nielsen SS. Introduction to the Chemical Analysis of Food. New York: Chapman and Hall; 1995.

7. Shahidi F, Nazck M. Food Phenolics. Basel: Technomic Publishing Company, Inc; 1995.

8. Othman A, Ismail A, Ghani NA, Adenan I. Antioxidant capacity and phenolic content of cocoa benas. Food Chemistry. 2007; 100: 15231530.

9. James CS. Analysis Chemistry of Food. Great Britain: Blackie Academic and Professional; 1995.

10. Ranggana S. Manual Of Analysis of Fruit and Vegetables Product. Tata. New Delhi: MC. Graw Publishing Company Limited; 1997.
11. Rahman A, Fardiaz S, Rahaju WP, Suliantari, Nurwitri CC. Teknologi Fermentasi Susu. Pusat Antar Universitas Pangan dan Gizi. Institut Pertanian Bogor; 1992.

12. Lin MY, Yen CL. Reactive Oxygen Species and Lipid Peroxidation Product-Scavenging Ability of Yogurt Organisms. Department of Food Science, National Chung Hsing University, Taichung 402, Taiwan. Journal Dairy Science. 2004; 82:1629-1634.

13. Battcock M, Azam-Ali S. Basic Principles of Fermentation. FAO Agricultural Services Bulletin No. 134. United Kingdom: Intermediate Technology, Schumacher Centre for Technology and Development; 1998.

14. Liu JR, Chen MJ, Lin CW. Antimutagenic and Antioxidant Properties of Milk-Kefir and Soymilk-Kefir. Department of Animal Science, National Taiwan University and Institute of BioAgricultural Sciences. 2004; $1-8$.

15. Rahman A. Pengantar Teknologi Fermentasi. IPB Bogor: Pusat Antar Universitas Pangan dan Gizi; 1989.

16. Yusmarini, Efendi R. Evaluasi Mutu Soygurt yang dibuat dengan Penambahan beberapa Jenis Gula. Jurnal Natur Indonesia. 2004; 6(2): 104110.

17. Seyis I,Aksoz N. Production of Lactase By Trichoderma Sp., Food Technol. Biotechnol. 2004; 42 (2): 121-124.

18. Baumgartner C, Freydiere AM, Gille Y. Direct Identification and Recognition of Yeast Species from Clinical Material by Using Albicans ID and CHROM agar Candida Plates. Journal Of Clinical Microbiology. 1996; 34(2): 454-456.

19. Surono IS. Probiotik, Susu Fermentasi dan Kesehatan. Jakarta: Yayasan Pengusaha Makanan dan Minuman Seluruh Indonesia (YAPMMI). TRICK; 2004. 